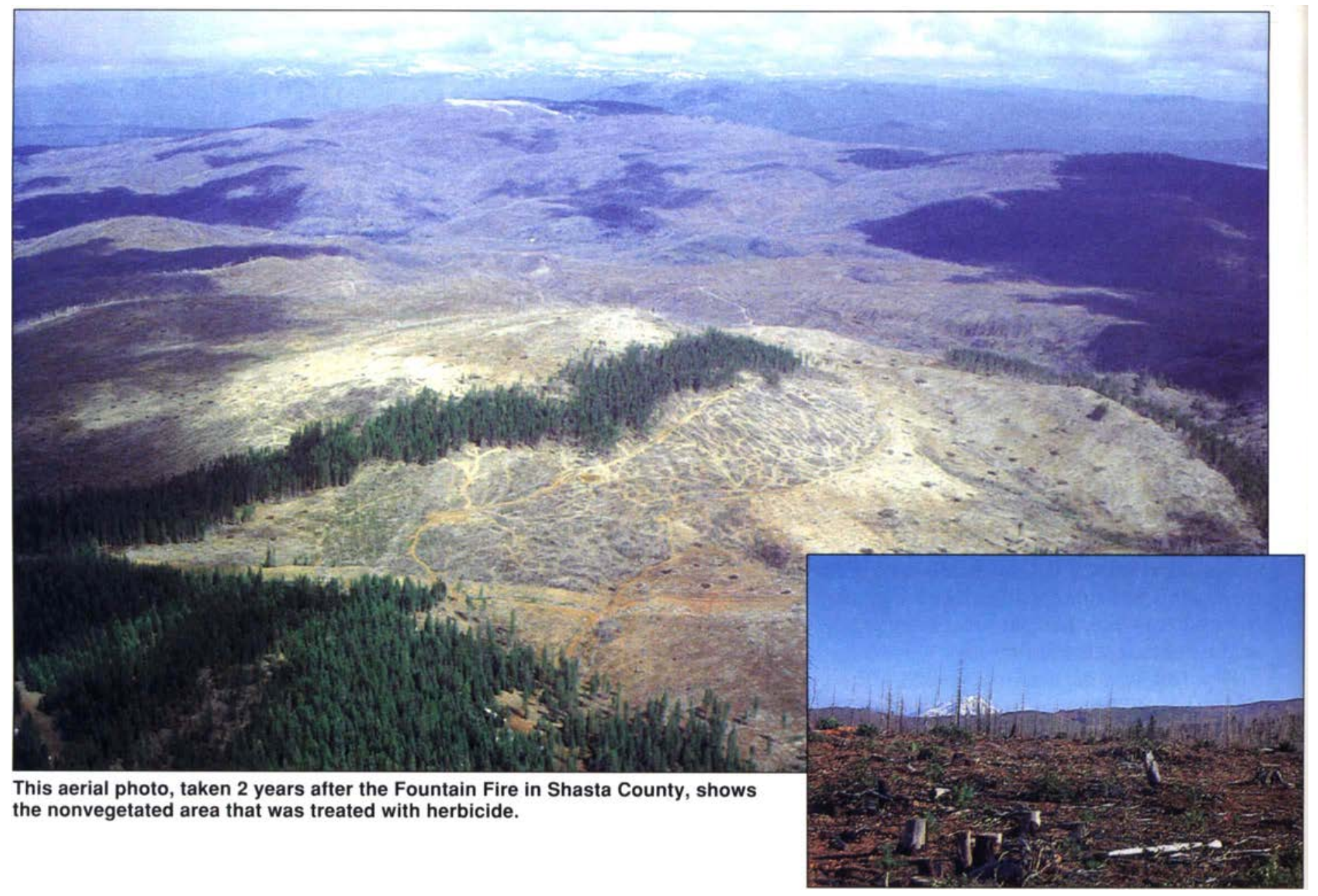

\title{
Post-fire herbicide sprays enhance native plant diversity
}

\begin{abstract}
A Two-year old conifer plantation after the site was treated with the herbicide hexazinone. Ponderosa pine were hand transplanted after site preparation. Pink flags represent the end of line transects.
\end{abstract}

\author{
Joseph M. DiTomaso \\ a Daniel B. Marcum \\ 口 \\ Michelle S. Rasmussen \\ Evelyn A. Healy $\square$ Guy B. Kyser
}

\begin{abstract}
Following catastrophic fire, broad-spectrum herbicides such as hexazinone are often used to control shrubs and forbs that compete with planted conifers. This practice encourages rapid growth and reduces mortality of conifers. Although the initial effect is to reduce native plant species richness, recovery is rapid and plant diversity exceeds that in untreated areas within 8 years of application. Success of native forb and grass species in herbicide-treated areas appears to be due to early suppression of otherwise dominant shrubs.
\end{abstract}

In August of 1992 the Fountain Fire burned 64,000 acres $(25,900$ hectares) of forest in eastern Shasta County. Nearly all the burned area was privately owned, principally by timber companies. In much of this area, the remaining fire-killed and damaged trees were salvage logged and the site replanted with native coniferous species, primarily ponderosa pine (Pinus ponderosa), but also including Douglas fir (Pseudotsuga menziesii), white fir (Abies concolor) and incense cedar (Calocedrus decurrens). Prior to transplanting the conifer seedlings, these sites were treated with the broad-spectrum herbicide hexazinone.
The beneficial effects of hexazinone in conifer site preparation have been recognized since the herbicide was first introduced in the late 1970s. The residual soil activity of hexazinone can persist for a couple of years, thus encouraging rapid conifer establishment by reducing the competitive effect of other woody and herbaceous species. However, the relatively barren appearance of landscapes resulting from this forestry practice has raised public concern as to whether native plant diversity can recover from hexazinone treatment. By comparison, untreated areas appear green and lush with vegetation within 2 years of the catastrophic fire. 
Little is known of the influence of herbicides on long-term plant richness and animal diversity in forests, rangeland and wildland areas. Recovery in both plant diversity and small mammal communities was reported within 2 years of glyphosate application in a Canadian sub-boreal spruce forest. Unlike glyphosate, which has no soil activity, hexazinone is a soil-active herbicide that suppresses competing plant growth for up to 2 years in most areas.

Direct measures of plant composition changes in a specific burn site require long-term monitoring with several years of sampling. An alternative to long-term monitoring of one site is to substitute space for time and to examine older fires that were similarly treated. In eastern Shasta County, intense wildfires have also occurred in comparable mixed-conifer forests adjacent to the Fountain Fire region in 1986 (Tamarack Fire) and 1977

(Pondosa Fire). In these areas, reforestation practices were similar to those used after the Fountain Fire (table 1). Therefore it is likely that these older sites would be representative of the changes in the reforested Fountain Fire site 9 (Tamarack Fire) and 17 (Pondosa Fire) years later.

In addition to examining the vegetation in the burned and herbicidetreated sites, a portion of each of these three fire sites was cleared and replanted with conifers, but not treated with herbicide. Thus an indirect measure of conifer establishment, plant diversity and species richness could be achieved in a single season by sampling and comparing the vegetative composition and structure in herbicide-treated and untreated plots located in each of these fire sites.

\section{Experimental design}

In each fire location (Fountain, Tamarack and Pondosa), we established a single field plot ( 164 by 525 feet; 50 by 160 meters) in herbicidetreated and untreated burned areas, and in a similar and adjacent mixed-

TABLE 1. History and forestry practices in experimental sites

\begin{tabular}{|c|c|c|c|c|c|}
\hline $\begin{array}{l}\text { Experimental } \\
\text { site }\end{array}$ & Fire & $\begin{array}{c}\text { Site } \\
\text { preparation }\end{array}$ & $\begin{array}{l}\text { Planted or } \\
\text { germinated }\end{array}$ & Aspect & Elevation \\
\hline \multirow{3}{*}{ Fountain } & Underburned & None & Pre-1943 & sw & $\begin{array}{c}t t \\
3.610\end{array}$ \\
\hline & Burned in 1992 & $\begin{array}{l}1993 \text { - aerial hexazinone } \\
\text { (Pronone, } 25 \text { lb/acre) }\end{array}$ & 1993 & w & 3,855 \\
\hline & Burned in 1992 & herbicide skips & 1993 & w & 3,855 \\
\hline \multirow[t]{3}{*}{ Tamarack } & $\begin{array}{l}\text { Underburned } \\
\text { Burned in } 1986\end{array}$ & $\begin{array}{l}\text { None } \\
1986 \text { - cleared }\end{array}$ & Pre-1943 & NW & 3,250 \\
\hline & & $\begin{array}{l}1987 \text { - aerial hexazinone } \\
\text { (Velpar-L, } 4 \text { qts/acre) }\end{array}$ & 1988 & W to NW & 3,610 \\
\hline & Burned in 1986 & 1986 - cleared & 1988 & w & 3,400 \\
\hline \multirow[t]{5}{*}{ Pondosa } & Underburned & None & Pre-1943 & Flat & 3,640 \\
\hline & Burned in 1977 & $\begin{array}{l}1980 \text { - cleared } \\
1981 \text { - burned windrows }\end{array}$ & & & \\
\hline & & $\begin{array}{l}1983 \text { - aerial hexazinone } \\
\text { (Velpar-L, } 6 \text { qts/acre) }\end{array}$ & 1981 & Flat & 3,775 \\
\hline & Burned in 1977 & 1980 - cleared & & & \\
\hline & & 1981 - burned windrows & 1981 & Flat & 3,775 \\
\hline
\end{tabular}

TABLE 2. Effect of hexazinone treatment on conifer height, stem diameter and density in three fire sites of varying ages

\begin{tabular}{|c|c|c|c|c|c|c|}
\hline \multirow[b]{2}{*}{ Fire site } & \multicolumn{2}{|c|}{ Height } & \multicolumn{2}{|c|}{ Stem diameter } & \multicolumn{2}{|c|}{ Conifer density* } \\
\hline & $\begin{array}{l}\text { Herbicide- } \\
\text { treated }\end{array}$ & Untreated & $\begin{array}{l}\text { Herbicide- } \\
\text { treated }\end{array}$ & Untreated & $\begin{array}{l}\text { Herbicide- } \\
\text { treated }\end{array}$ & Untreated \\
\hline & \multicolumn{2}{|c|}{............ feet ................. } & \multicolumn{2}{|c|}{ 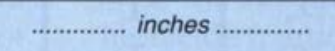 } & \multicolumn{2}{|c|}{...... plants $/ 1,076 \mathrm{ft}$} \\
\hline Fountain $(2 \mathrm{yrs}) \dagger$ & 1.6 & $0.9(54) \ddagger$ & 0.55 & $0.25(46)$ & - & - \\
\hline Tamarack (7 yrs) & 11.7 & $5.8(50)$ & 3.78 & $1.89(50)$ & 7.8 & $2.3(29)$ \\
\hline Pondosa (14 yrs) & 17.8 & 9.5 (53) & 5.75 & $2.40(42)$ & 7.1 & $0.7(10)$ \\
\hline
\end{tabular}

- Conifer density at Fountain Fire site undetermined because seedlings naturally regenerated.

† Years since conifer planting or germination.

¥ Numbers in parentheses represent percent of herbicide treatment. In each case, the values for treated areas were significantly different $(P<0.05)$ from untreated areas.

conifer forest, which was underburned but not consumed by the fire. Reforestation practices following the Tamarack (1986) and Pondosa (1977) fires were similar to those used in the Fountain Fire, and included salvage logging of older trees, removal of logged debris, ripping to break up soil compaction, planting of conifer seedlings and herbicide treatment (table 1).

Primarily ponderosa pine was planted in the Tamarack (some Jeffery pine) and Pondosa (some Douglas fir) sites to a final density of approximately 9 trees $/ 1,076 \mathrm{ft}^{2}\left(100 \mathrm{~m}^{2}\right)$, or 364 trees/acre. Very little natural recruitment of trees occurred in these sites. This is also true for most of the Fountain Fire. However, in the study site used in the Fountain burn (herbi- cide-treated and untreated), existing ponderosa pine established through naturally occurring regeneration, with no additional conifers planted.

Conifer size was determined by measuring the height and diameter (2 inches above the soil surface) of 25 randomly selected seedlings in the Fountain Fire site or by recording the height and diameter of randomly selected older trees below the first branch in the 9-year-old Tamarack and 17-year-old Pondosa fire areas. Conifer density was determined by counting the number of conifers in randomly selected 33-by-33-foot (10-by-10-meter) plots in each site (four replicates per site).

Vegetative cover was estimated at each site by determining the species 


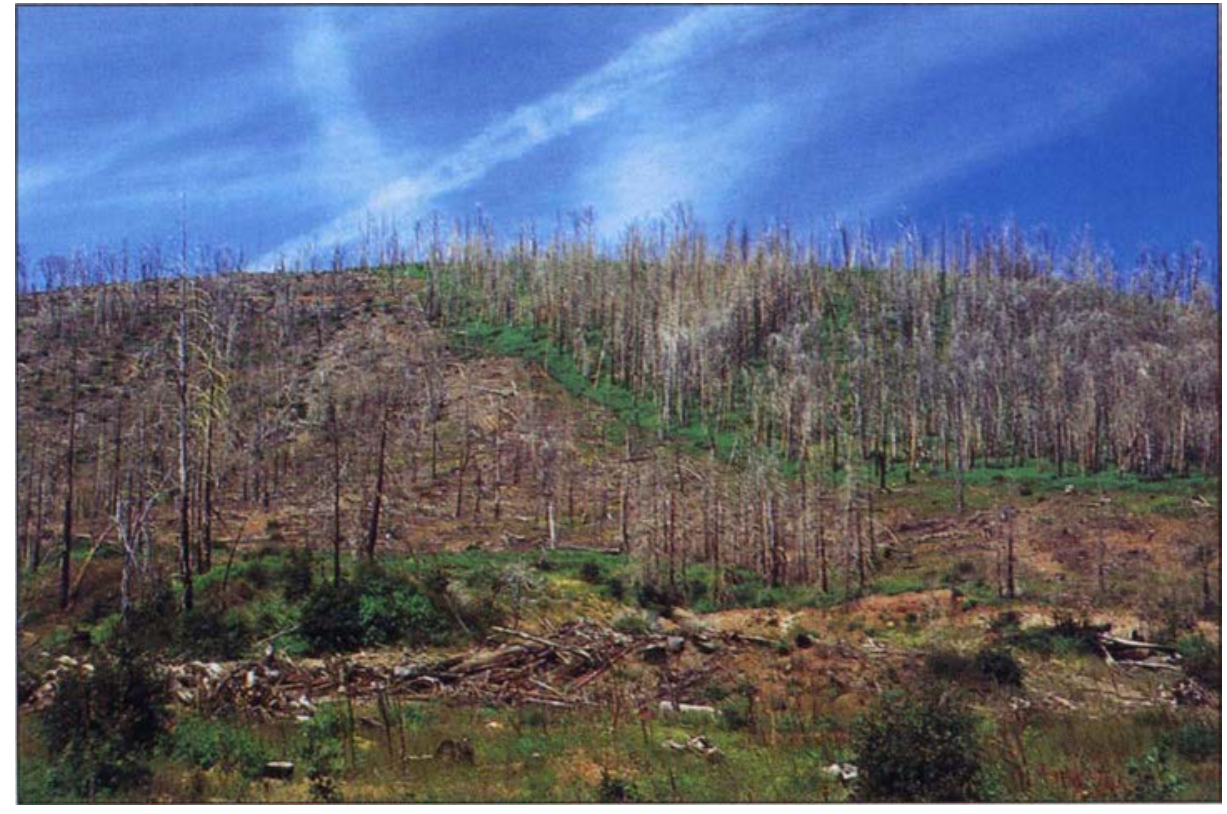

Area on the left has been treated with herbicide. Mixed shrubs shown in the untreated area on right will compete with establishing conifers.

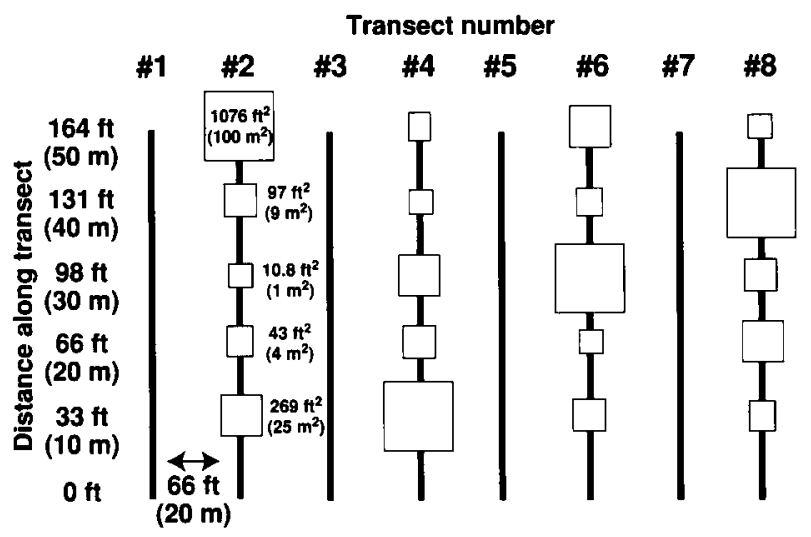

Fig. 1. Experimental design with eight line transects per plot and species richness quadrats. Vertical line intercept every 3.3 feet ( 1 meter); quadrat centered every 33 feet ( 10 meters) along alternate transects.

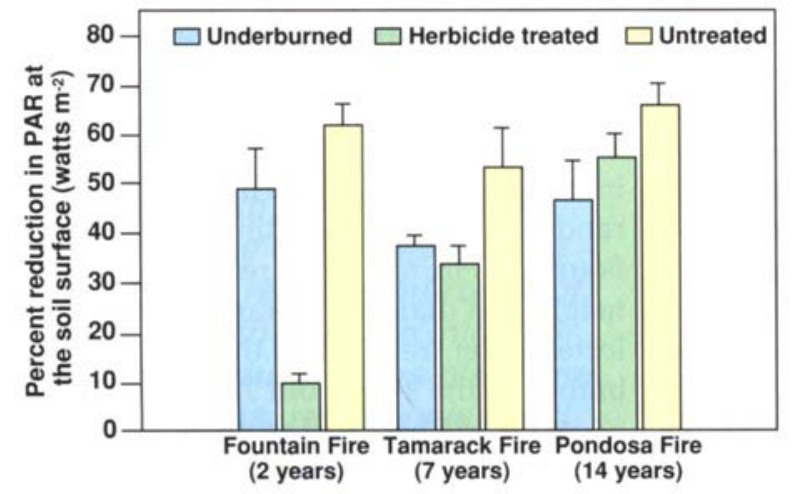

Fig. 2. Reduction in light interception (PAR = photosynthetically active radiation) at soil surface in underburned and herbicide-treated and untreated burned areas in three fire sites of varying ages. Years in parentheses below fire represent time since seedling planting. Bars represent one standard deviation from the mean. intervals along all eight line transects (80 total measurements/plot).

\section{Conifer establishment}

Herbicide treatment had a dramatic and statistically significant effect on conifer height and stem diameter at each site (table 2). This difference was apparent even 2 years after conifer establishment (Fountain Fire), where herbicide treatment resulted in a doubling of both height and stem diameter. The relative difference between the herbicide-treated and untreated sites in both height and stem diameter was similar for each fire location, ranging from a $46 \%$ to $58 \%$ reduction in the untreated areas. More importantly, when the herbicide was not applied, conifer mortality rates increased noticeably as the shrub layer developed. Assuming that conifers were initially planted at approximately 9 trees $/ 1,076 \mathrm{ft}^{2}\left(100 \mathrm{~m}^{2}\right)$, or 364 trees/ acre, herbicide-treated sites exhibited $87 \%$ conifer survival 7 years after planting in the Tamarack Fire area, and $79 \%$ survival 14 years after planting in the Pondosa Fire area. In contrast, survival was only $26 \%$ and $8 \%$ in the untreated Tamarack and Pondosa fire areas, respectively.

\section{Light interception}

It is well recognized that shrub competition can dramatically reduce young conifer growth. Similar results are reported in these experiments. In the untreated areas of both the Fountain and Tamarack fires, deerbrush (Ceanothus integerrimus) was the dominant species, representing $64 \%$ and $34 \%$ of the total vegetative cover, respectively. In the untreated Pondosa site, the dominant species $(42 \%$ total cover) was greenleaf manzanita (Arctostaphylos patula). The presence of these and other competing species was closely correlated with light reduction at the soil surface (fig. 2). In the most recent fire (Fountain), less than $40 \%$ of the available PAR contacted the soil surface in the untreated areas. This level of light suppression was not significantly different from that in the unburned forest. By comparison, over $90 \%$ of PAR reached the soil in the treated plots. 
Light penetration did not differ statistically among the three fire sites for both the underburned and untreated plots. However, a significant decrease in light level was measured in the herbicide-treated site as the time since the fire increased. This reduction in light penetration with time was due to the rapid establishment and growth of the conifers.

Although soil moisture levels were not measured, competition for available moisture by surrounding vegetation is probably the most important resource limiting the growth of conifers in the untreated areas. These findings demonstrate the effectiveness of hexazinone in reducing brush competition for available resources.

\section{Vegetative cover}

Total vegetative cover for each species was determined in all plots. Findings from these measurements were simplified by combining cover for each species into vegetative types, including conifers, broadleaf shrubs, forbs and grasses (table 3). Because two or more species may be encountered at a single sample point, a total value of over $100 \%$ (bare ground + all vegetation types) may result.

As might be expected, the bare ground level was significantly greater 2 years after hexazinone application in the Fountain Fire site. Treated areas had only $6 \%$ vegetative cover, contrasting with $82 \%$ cover in the untreated site and $81 \%$ cover in the unburned forest. Most notably, the total broadleaf shrub cover in the untreated burned area was nearly twice that of

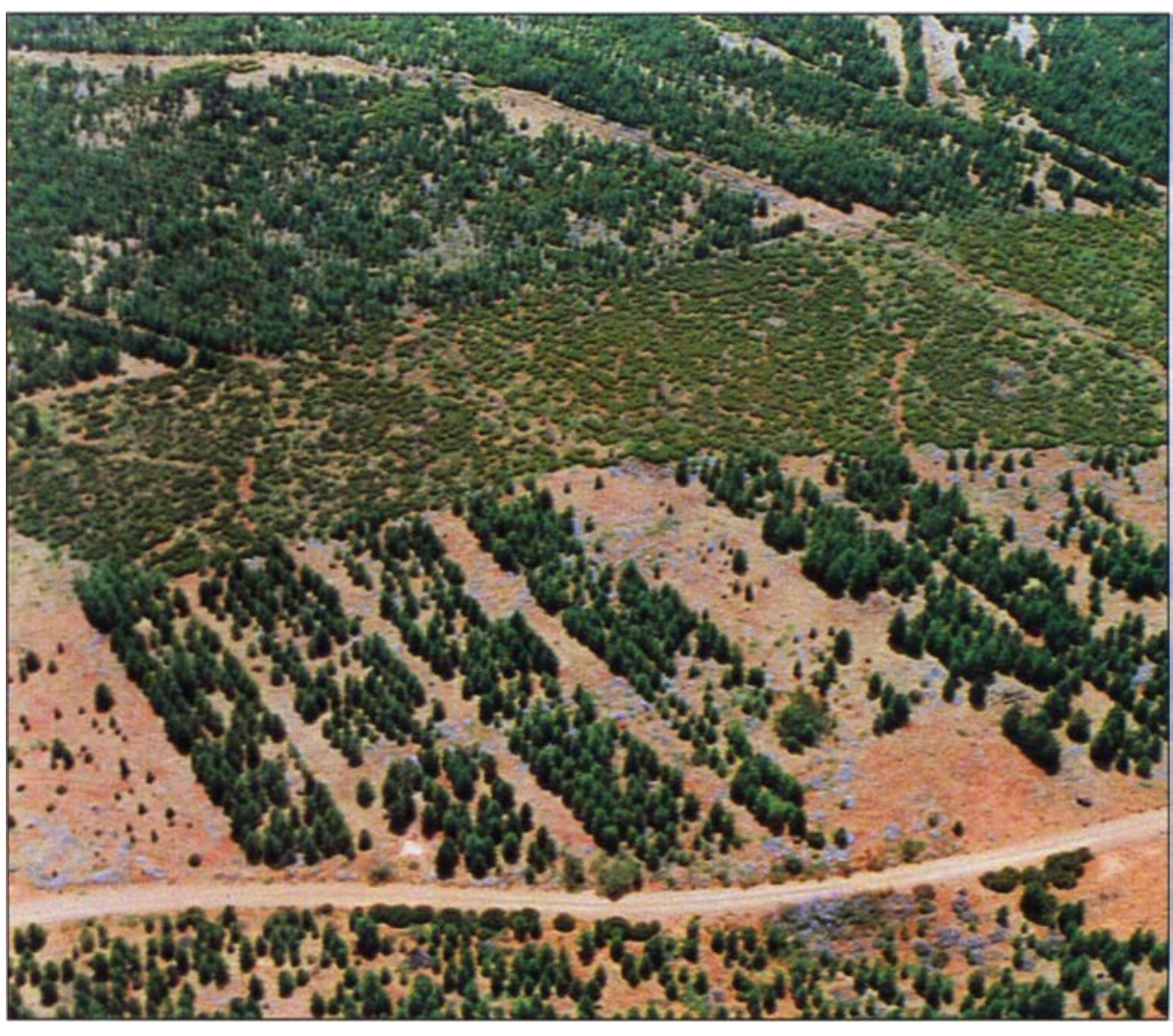

The site of the Pondosa Fire was treated with hexazinone in 1988 with a wide swath in the middle left untreated. This photo taken in 1994 shows the treated area is filled with ponderosa pine whereas the untreated area is primarily populated by the lighter green shrubs.

the unburned site. Furthermore, conifer crown cover in the untreated plot was four times less than in the hexazinone-treated area, again demonstrating the detrimental effect of early shrub competition on conifer seedling establishment. Although erosion was not measured in the treated or untreated areas, it is possible that reduced vegetative cover resulting from herbicide treatment may affect soil stability during the first few years following treatment.
In the Tamarack region 8 years after herbicide treatment, bare ground and total vegetative cover were similar among underburned plot and the herbicide-treated and untreated burned sites. Whereas the cover of most vegetation types in the herbicidetreated site was similar to that of the unburned area (only grass cover was reduced), the untreated region had less conifer and forb cover, and again significantly higher broadleaf shrub cover.

TABLE 3. Comparison of vegetative cover with and without herbicide treatment for vegetative management

\begin{tabular}{|c|c|c|c|c|c|c|c|c|c|}
\hline \multirow[b]{2}{*}{ Vegetation type } & \multicolumn{3}{|c|}{ Fountain Fire ( 2 years) ${ }^{*}$} & \multicolumn{3}{|c|}{ Cover } & \multicolumn{3}{|c|}{ Pondosa Fire (12 years) } \\
\hline & $\begin{array}{l}\text { Under- } \\
\text { burned }\end{array}$ & Treated & Untreated & $\begin{array}{l}\text { Under- } \\
\text { burned }\end{array}$ & Treated & Untreated & $\begin{array}{l}\text { Under- } \\
\text { burned }\end{array}$ & Treated & Untreated \\
\hline & & & & & $\ldots . . \% \ldots$ & & & & \\
\hline Bare ground & 37 at & $95 \mathrm{~b}$ & $19 \mathrm{a}$ & $17 \mathrm{a}$ & $29 a$ & $18 \mathrm{a}$ & $21 \mathrm{a}$ & $15 a$ & $16 \mathrm{a}$ \\
\hline Conifers & $30 a$ & $4 \mathrm{~b}$ & $1 \mathrm{~b}$ & $23 a$ & $22 \mathrm{a}$ & $7 \mathrm{~b}$ & $25 \mathrm{a}$ & $51 \mathrm{~b}$ & $1 \mathrm{c}$ \\
\hline Broadleaf shrubs & $39 a$ & $1 \mathrm{~b}$ & $75 c$ & $2 a$ & $7 \mathrm{a}$ & $44 \mathrm{~b}$ & $2 a$ & $11 \mathrm{a}$ & $103 \mathrm{~b}$ \\
\hline Forbs & $10 \mathrm{a}$ & $1 \mathrm{~b}$ & $5 a b$ & $49 a$ & $36 \mathrm{a}$ & $17 \mathrm{~b}$ & $28 \mathrm{a}$ & $14 \mathrm{ab}$ & $5 b$ \\
\hline Grasses & $2 \mathrm{a}$ & $0 \mathrm{a}$ & $1 \mathrm{a}$ & $54 \mathrm{a}$ & $31 \mathrm{~b}$ & $45 a b$ & $45 \mathrm{a}$ & $49 \mathrm{a}$ & $14 \mathrm{~b}$ \\
\hline $\begin{array}{l}\text { Non-native } \\
\text { vegetation } \\
\text { (\% relative cover) }\end{array}$ & $2.8 \mathrm{a}$ & $0 \mathrm{a}$ & $0.3 a$ & $5.4 \mathrm{a}$ & $28.7 b$ & $40.3 \mathrm{c}$ & $3.5 \mathrm{a}$ & $3.0 \mathrm{a}$ & $0.5 \mathrm{a}$ \\
\hline
\end{tabular}


In the oldest burn site (Pondosa), only conifer cover differed significantly between the herbicide treatment and the unburned forest. While the herbicide-treated area exhibited the highest conifer cover, few conifers were encountered in the untreated area. The untreated Pondosa plots again displayed significantly higher broadleaf shrub cover but statistically lower forb and grass cover than the unburned forest. Presumably the denser shrub cover in the untreated area resulted in suppression of both conifers and herbaceous species.

Interestingly, herbicide treatment had no significant effect on the total number and cover of non-native species in the Fountain and Pondosa fire areas. In the Tamarack Fire area, the relative cover of non-native species was lowest $(5.4 \%)$ in the unburned site, but statistically highest $(40.3 \%)$ in the untreated burned site. The increase in non-native vegetative cover was due to the predominance of downy brome or cheatgrass (Bromus tectorum) in both the herbicide-treated and untreated burned sites.

\section{Plant diversity}

A number of formulas can be used to calculate relative differences in plant and animal diversity in a particular study area. Two commonly used indices are the Shannon (Shannon-Wiener) and Simpson formulas. These indices depend on both the number of species and the proportion of each species present. Typically the Shannon index is used in larger communities than the Simpson index. A more recent index was developed by Bulla in 1994. This index gives equal weight to all species independent of their abundances. Because the interpretation of changes in plant diversity based on any single formula can be limited, we used all three indices to better ascertain the effect of hexazinone treatment on plant diversity.

In addition to having no long-term effect on vegetative cover compared to unburned sites, herbicide treatment did not significantly influence longterm plant diversity or mean number of species recorded per transect (table 4). Plant diversity in both the herbicide-treated and untreated plots of the Fountain Fire site was very low relative to the unburned forests. This difference was no longer significant in the treated Tamarack and Pondosa sites. However, plant diversity indices in the untreated areas of the Tamarack Fire and particularly the Pondosa Fire were statistically lower compared to those of the underburned or herbicidetreated plots using all three diversity indices.

Using an additional method, we tested for changes in species richness by determining the total number of species in quadrats of varying sizes. Plot size affects the number of species observed, with more species found in larger plots. Plotting log species number by log plot size produces straight lines ( $r^{2}$ values between 0.85 and 0.99$)$ whose slopes indicate the rate at which number of species increased with plot size (fig. 3). Lines higher on the graph have more species for a plot of a given size. Species richness in the Fountain Fire area was greatest in the underburned forest, intermediate in the untreated area and least in the herbicide-treated areas.

Although richness was lowest in the herbicide-treated area, species numbers among the three treatments were similar in the $1,076-\mathrm{ft}^{2}\left(100-\mathrm{m}^{2}\right)$

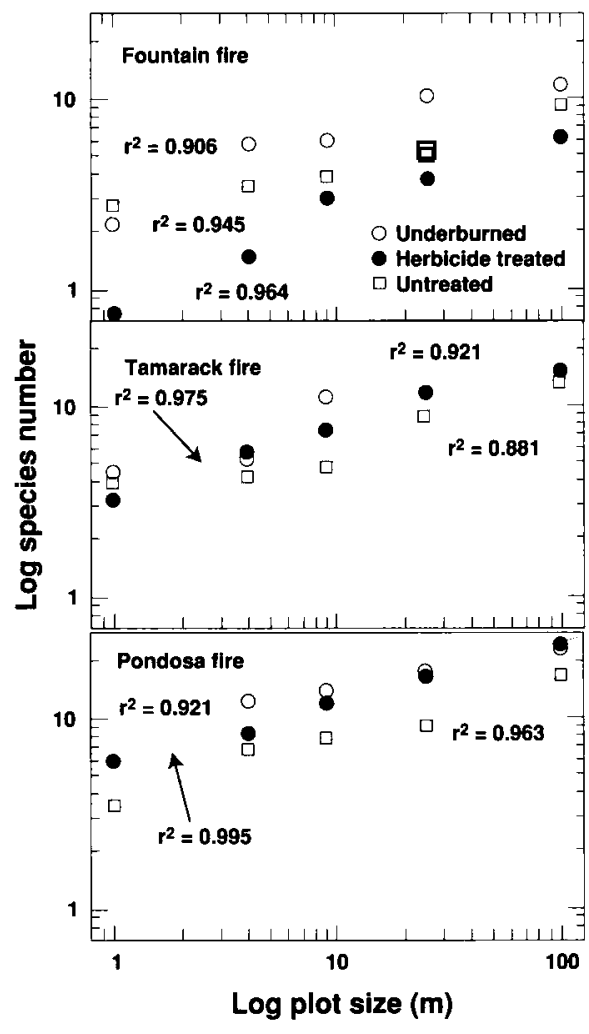

Fig. 3. Log-log transformation of species richness (total species number) data from quadrats of varying sizes in underburned areas and herbicide-treated and untreated areas. 
plots. At Tamarack, species richness was also greatest in the underburned areas, but herbicide-treated areas exceeded untreated areas. At this site, the area without a herbicide treatment demonstrated the lowest slope as well as the smallest number of species at each quadrat size. Species richness was nearly identical between the herbicide-treated and underburned forest at Pondosa, whereas species richness in the untreated site was significantly reduced. These results support the finding obtained using the plant diversity indices.

There was little apparent change in the species composition between the untreated and the herbicide-treated areas.

\section{Conclusions}

Results of this investigation demonstrate the importance of herbicide site preparation for successful reforestation following catastrophic fire. In the absence of shrub control, competition for water (and perhaps light) can lead to the suppression of both conifer seedlings and many of the indigenous native herbaceous species.

Despite the initial reduction in plant diversity and species richness in herbicide-treated areas, the native plant diversity was not statistically different from that of the unburned forest sites 8 years after the treatment. In contrast, untreated burned areas demonstrated a long-term reduction in plant diversity and species richness compared to the unburned site. Although the untreated area had a similar level of vegetative cover to the unburned or herbicide-treated site, the vegetation was dominated by only a few shrubby species, particularly Ceanothus spp. and Arctostaphylos patula.

J.M. DiTomaso is Non-Crop Extension Weed Ecologist, Department of Vegetable Crops, UC Davis; D.B. Marcum is Farm Advisor, Shasta-Lassen Counties; M.S. Rasmussen and E.A. Healy are summer interns, UC Davis; and G.B. Kyser is Research Support, Department of Vegetable Crops, UC Davis.

This research was supported by UCDANR North Region.

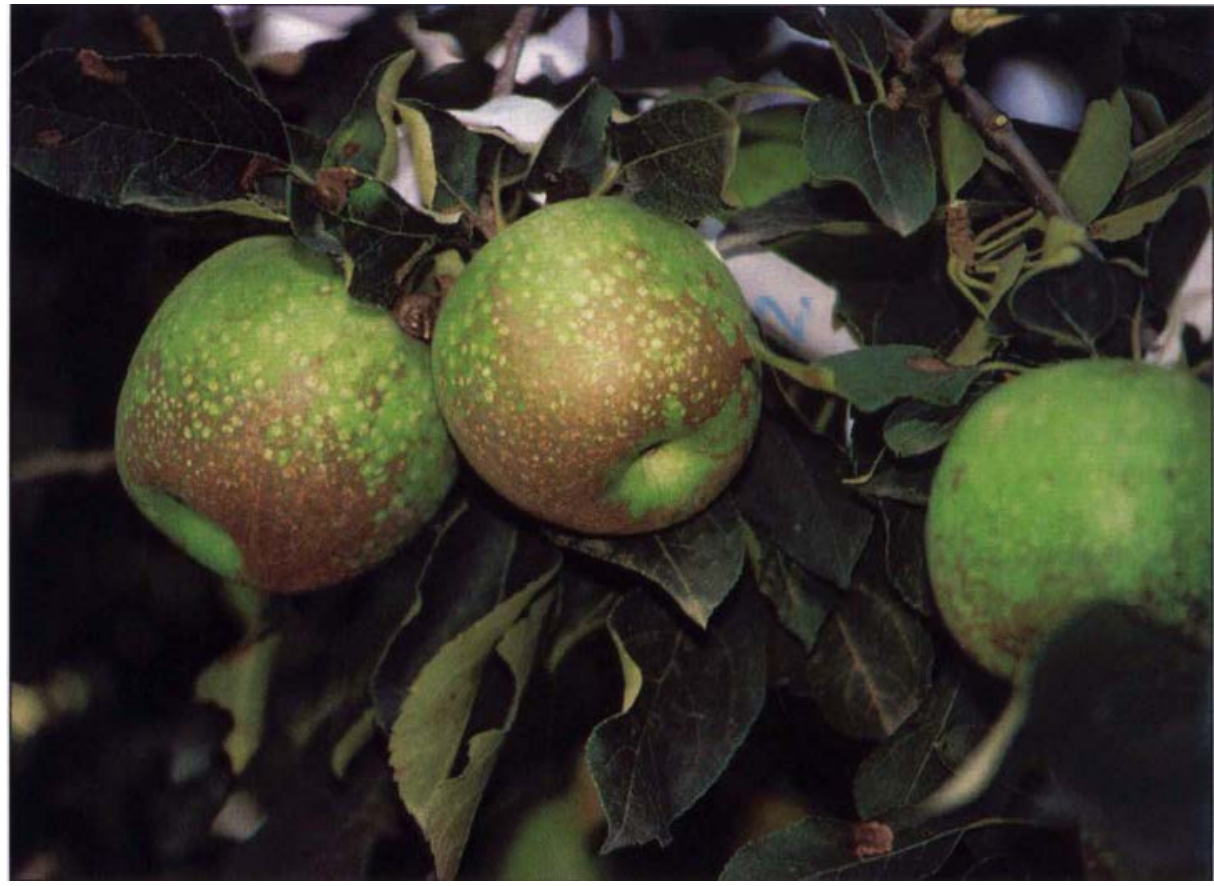

The severity of russetting on Granny Smith apples increased with increasing numbers of copper treatments used to control fire blight during bloom.

\title{
Apple russetting influenced by more than copper sprays
}

\author{
Beth L. Teviotdale $\square$ Mario Viveros $\square$ Joseph A. Grant
}

Apple trees are commonly treated with antibiotics during bloom and early shoot growth to control fireblight, but antibiotic resistance is a concern. To prevent antibiotic resistance, copper treatments may be beneficial, but would be feasible only if stages in bloom or fruit development could be identified that are not subject to fruit russetting. Most fruit russetting results from injury to epidermal cells early in fruit development. Studies in Kern and San Joaquin counties showed copper-induced russetting of apple fruit was unpredictable and sporadic regardless of application timing. Severity of damage varied from year to year.
Apple trees are susceptible to fire blight, a bacterial disease that kills flowers and young shoots. In very susceptible cultivars the disease can destroy large scaffolds or entire trees. The pathogen, Erwinia amylovora, overwinters in the tree and is spread in spring chiefly by rain and insects. Infections occur mainly through flowers, although succulent vegetative shoots are also attacked. Fire-blight epidemics are promoted by moderate temperatures and wet or humid weather during bloom. Fire blight is controlled with bactericide treatments during and shortly after bloom, removal of infected shoots or branches throughout the year and specific cultural practices such as avoiding irrigation during bloom and limiting nitrogen fertilization. 